\title{
Motivations, engagement, and benefits as drivers of collective value co-creation in event tourism
}

\section{Francesca Cabiddu, University of Cagliari Gianluca Vagnani, University of Rome}

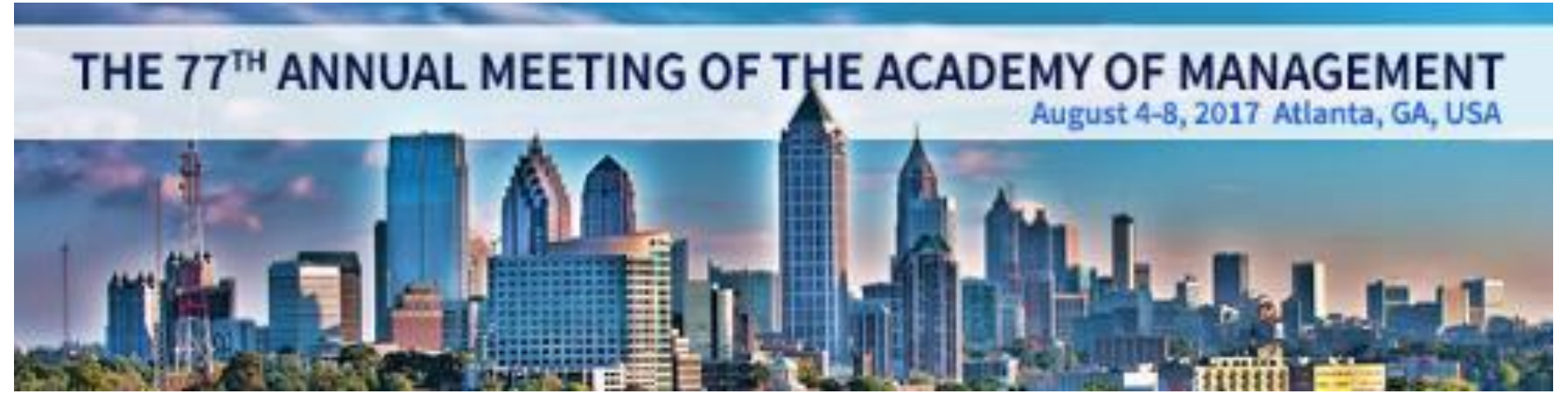




\section{Introduction}

$\square$ A growing number of tourism marketing studies have explored the concept of value co-creation (Cabiddu, 2013; Prebensen, Vittersø, \& Dahl, 2013).

$\square$ The core argument of this stream of research is that the success of an event depends on the total value co-created; and this value stems primarily from the interaction between an organization and each of its own customers. 


\section{Motivation}

$\square$ While the current body of knowledge is generally rich in conceptualizing value co-creation, the collective dimension of the value co-creation is partially captured, and calls to articulate explicit frameworks are commonly made (Edvardsson, Tronvoll, \& Gruber, 2011; Laamanen \& Skalen, 2015)

$\square$ Collective action is undertaken by people together to enhance their status and achieve some common objectives (Laamanen \& Skalen, 2015). 


\section{Goal}

$\square$ Goal: Thus, the aim of this article is to explicate a collective perspective on value co-creation and generate a framework showing the driving factors of the collective value co-creation at the event tourism level

$\square$ We define event tourism as "inclusive of all planned events in an integrated approach to development and marketing " (Getz, 2008, p. 404). 


\section{Methodology}

$\square$ A theory-building case study methodology (Eisenhardt, 1989)

$\square$ Research setting

- Tourism industry: Open Monuments (Monumenti Aperti)

$\square$ Data collection and sample selection:

- Semi-structured interviews

- Archival data 


\section{Case study: Open Monuments}

$\square$ Open Monuments is a cultural event born in 1997 to promote the knowledge of the cultural, artistic, archaeological, and historical heritage of Cagliari (Italy).

$\square$ Open Monuments in Cagliari happens every year on the month of May (two days), and it's when hundreds of monuments and gardens in Cagliari and Sardinia (Italy), that are normally closed to the public, are open and free to visitors. 


\section{Case study: Open Monuments}

$\square$ The event has grown up during the years involving nowadays more than 100 towns located in Sardinia.

$\square$ The event is animated by more than 2500 voluntaries coming from different schools, universities, and cultural associations working in Cagliari and Sardinia.

$\square$ Only in Cagliari, in the edition of 2017, there were approximately 100.000 visits with 78 sites open. 


\section{Data collection}

We interviewed:

- 7 organizers of the event (such as Members of the technical committee; Founder and cofounder of the event; etc.)

- 7 service providers who participated voluntarily in the delivery of the event (such as tourist guides; cultural Heritage operator: students)

- 5 other informants who have played simultaneously the role of organizers and providers. 


\section{Data analysis: Codification and final list of codes}

Individual motivations to cooperate

Volunteerism

Cognitive emotions (i.e. pride, passion)

Identification

Engagement

Involvement

Participation

Commitment
Individual benefits

Satisfaction

Visibility

Gratification

Collective value cocreation

Territorial relationship

Knowledge enhancement

Collective celebration 


\section{Findings: Individual motivations to cooperate}

\section{Informant}

Organizer

/Provider (5) "From an economic point of view, I am totally disinterested, however, I decided to commit myself to this initiative given its positive impact on our area. If there were other income sources, the event would not make much sense".

\section{Yes ( 6 out of 7 )}

Service

provider (7)

"I didn't choose to take part to this event neither for profit reasons nor for university credits but because I like it ".

Yes (7 out of 7)

"The initiative is not based on the economic aspect but on

volunteering: 13,000 volunteers with different levels of experience that in five weeks build up such a complex "machine"."

\section{Cognitive emotions}

Yes (4 out of 5)

"This event has generated a growing enthusiasm among the players involved. Enthusiasm is great, the guys are carefully prepared by the teachers who coordinate them with professionalism and enthuse them for this initiative".

\section{Yes (4 out of 7)}

$\ll I$ am proud for being part of this event, especially for the results achieved during these years".
Organizer (7).
Yes ( 2 out of 7 )

"We are pleased to show our monuments and we really do it with
Yes (7 out of 7) "I do not perceive it as a personal achievement but as a success of the team, many people working together".

\section{Yes (7 out of 7 )}

"Yes, I live the success of "Monumenti Aperti" very personally. After participating, you're happy and you feel you have made a contribution to science" 


\section{Findings: Theoretical framework}

\section{Figure 1 - Theoretical framework}

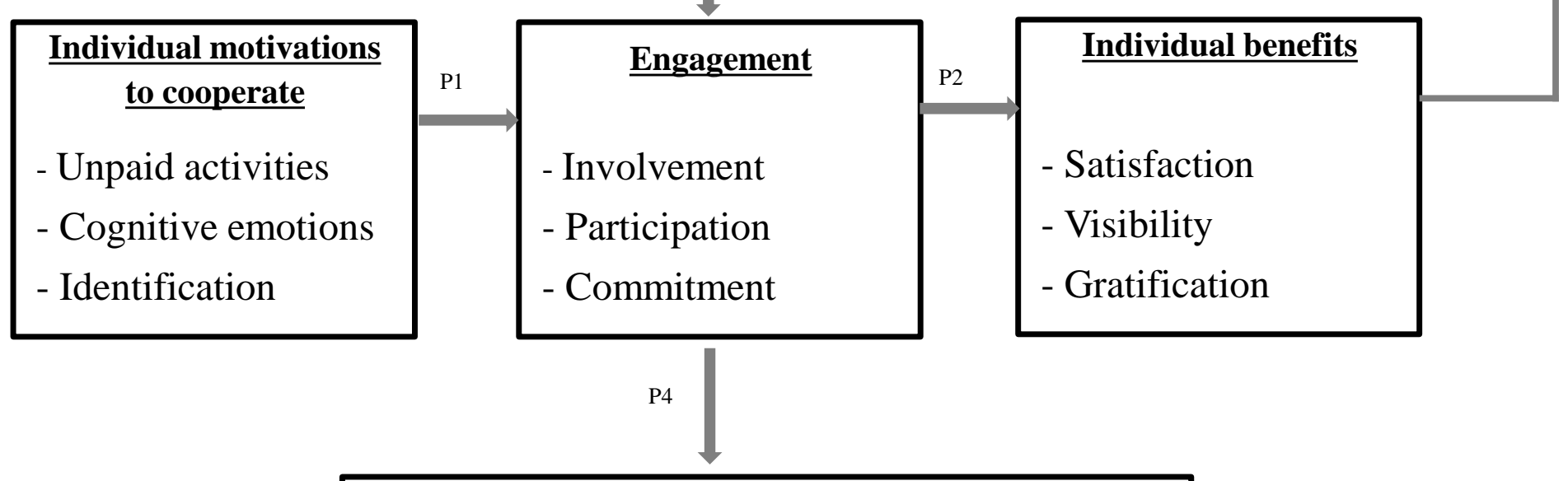

\section{Collective value co-creation}

- Territorial relationship

- Knowledge enhancement

- Collective celebration 


\section{Discussion and conclusion}

$\square$ Our study extend previous model to study value cocreation (Payne, Storbacka and Frow, 2008; Laamanen \& Skalen, 2015) exploring the nature of collective value cocreation in the context of event tourism:

$\square$ develop a conceptual framework for understanding the driving factors (individual motivation to cooperate, engagement and individual benefits) and the process that leads to collective value co-creation;

$\square$ show that the value that is collectively co-created could be distinguished in three different dimensions: territorial relationship, knowledge enhancement, and collective celebration. 


\section{Open Monuments}
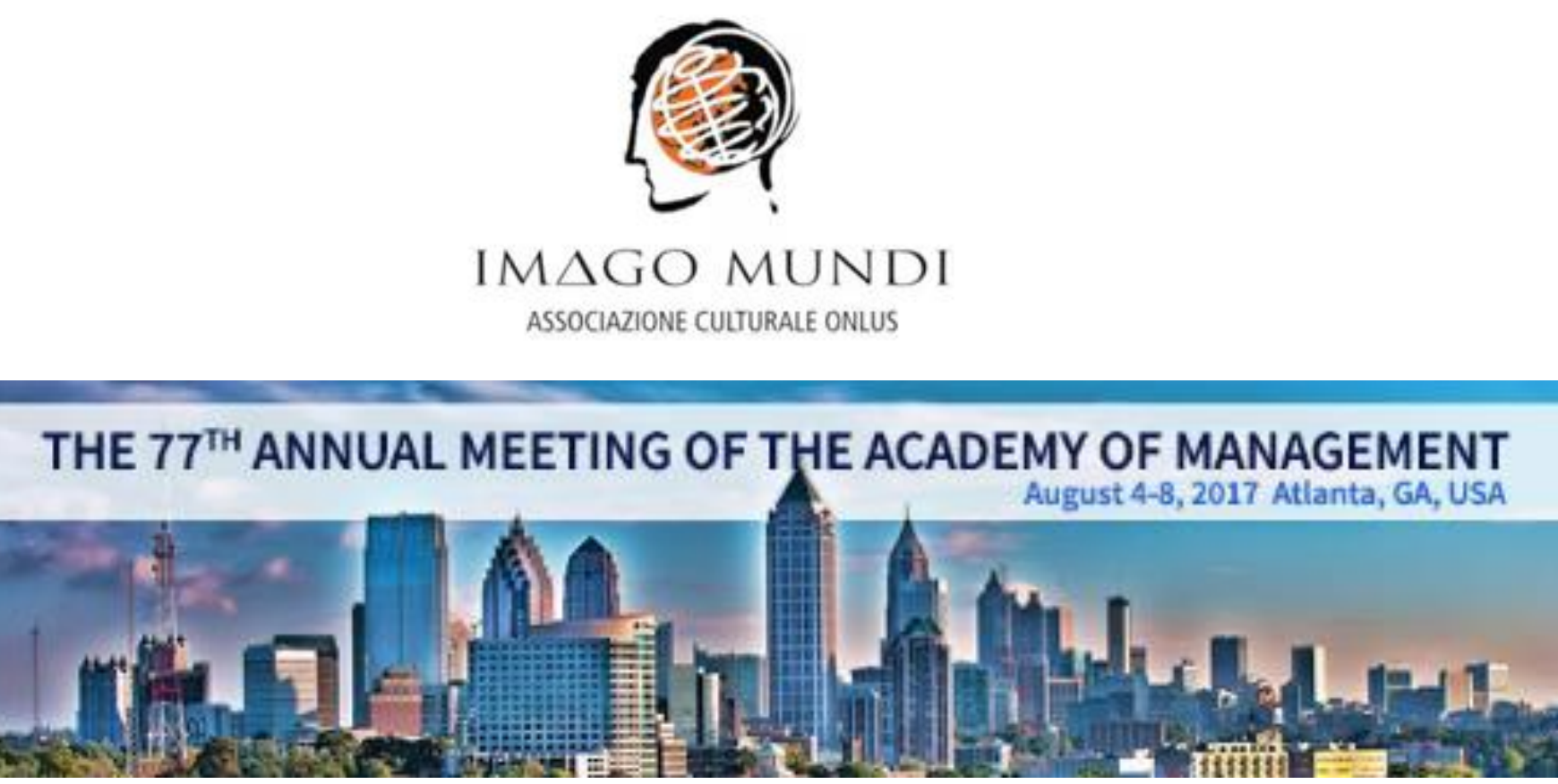


\section{Questions, comments, and suggestions are welcomed

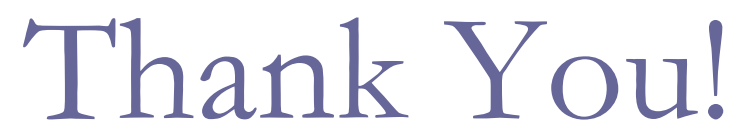

Francesca Cabiddu, University of Cagliari Gianluca Vagnani, University of Rome (Sapienza)

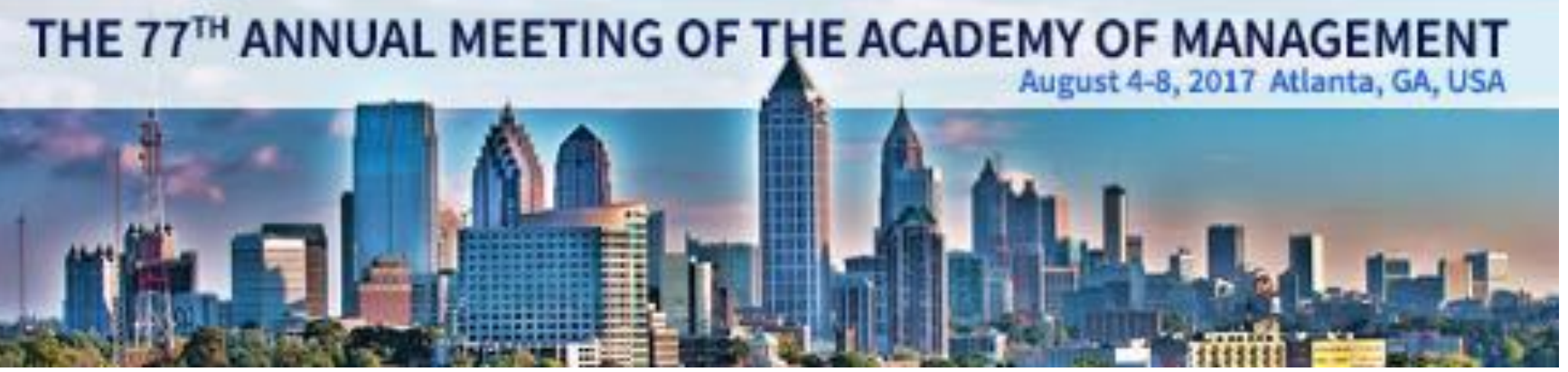

